\title{
Elements of the Bibliographic Record Used by Reference Staff Members at Three ARL Academic Libraries
}

\section{Jon R. Hufford}

This study determined the extent to which elements of a bibliographic record were consulted by reference staff members of three ARL libraries. It answered the following research questions: (1) For what purposes do reference staff use the catalog and/or database of a bibliographic utility? (2) Are the majority of catalog and utility database searches by the staff for known items? (3) Do the staff members use the author's name as the first access point more often than other access points? and (4) What is the incidence of use of each element of the record? The study raises the question of whether catalog and database use ought to play a part in cataloging theory and practice.

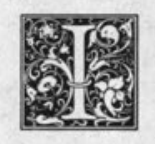

mprovements and changes in computer hardware and software affecting library online public access catalogs are expected to occur on a continuous basis for a number of years. While some variety exists in the structures of the presently existing online catalogs and the formats of their bibliographic records, greater variety will exist in the years to come as still more libraries install them. The potentialities the new computer technology offers for improving library OPACs have led some to conclude that this is an appropriate time to rethink the structure of catalogs. This rethinking should encompass both an empirical and a cumulative process, whose findings should be taken into account when librarians ultimately formulate a new cataloging code.

An important prerequisite of this restructuring process should be the collection of information on how existing catalogs are being used, how successfully they are used, what their limitations are, and what problems these limitations present to users of all types, including library staff members. Empirical catalog use studies that ascertain users' needs and behavior patterns when consulting catalogs and bibliographic utility databases provide this information. No evidence that previous catalog use studies ever influenced cataloging codes exists.

What is needed, according to Elaine Svenonius and Alan Seal, is a process of reexamination that focuses on answering such questions as:

What elements of description should be included in the record or records for each item, and how should they be arranged?

- What are to be the access points of these records?

- How should catalogs be arranged?

- How should codes be arranged?

- What should be the relationship between the organization and content of the catalog and catalog use? and

- What should be the relationship between cataloging codes and catalog use? ${ }^{1}$

Some of these questions have already been examined. For example, evidence 
drawn from empirical research has indicated what access points are needed and that library patrons are predominantly interested in only five elements of the bibliographic record: the author, title, subject headings, date of publication, and call number. ${ }^{2}$ However, the findings of most previous catalog use studies relate only to library patrons because these studies concentrated on use by patrons. The searching habits of all catalog user groups, including library staff members, should be studied. (In addition, a look at bibliographic record use may add to knowledge about problems with the quality of reference service.)

Undoubtedly, most librarians believe that major changes in cataloging practice are not likely to take place in the foreseeable future and that bibliographic records should be comprehensive. These librarians may argue that the records should be comprehensive because they are consulted at different kinds of libraries by many groups who use the records for different purposes. Other librarians may think that complete bibliographic records are necessary, if only for archival purposes. The rethinking process discussed in this study, which proposes that catalog and database use ought to play a part in the development of cataloging theory and practice, may seem out of step with these opinions. The foreseeable future has no incongruity. However, the rethinking process should occur over a lengthy period of time, perhaps decades, during which changes in cataloging practice, whether planned or otherwise, will most likely occur, despite what librarians may think now.

\section{AIM AND SCOPE}

This study investigated bibliographic record data elements which were sought in in-house catalogs and bibliographic utility databases, focusing on certain aspects of the proposed reexamination process and on a user group previously neglected by use studies. It covered one group of professional librarians and their supporting staff, all members of central reference departments of three academic institutions belonging to the Association of Research Libraries. The study was descriptive and quantitative in nature and not evaluative, and the findings apply only to the libraries studied. However, despite the former attribute, the findings may evoke judgments relating to quality of service performed by staff participating in the study. No attempt is made to determine or define the relative value of bibliographic elements, though use of elements by reference staff may indicate value. However, perceptions of the relative value of the elements as defined or implied in catalog codes, statements in the professional literature, or cataloging practice may affect the results of this descriptive study.

ARL libraries were selected because use of bibliographic elements would be heavier at these libraries than at other kinds of libraries. Reference department staff members were chosen for study because they often consult catalogs when assisting library patrons and when performing other tasks. The main libraries at Rutgers (the State University of New Jersey), New York University, and the State University of New York at Stony Brook were selected. Rutgers does not have a central library. Instead, the collections are dispersed among a number of libraries on several campuses. Two of the largest are Archibald Stevens Alexander Library, which houses the collections for the Humanities and the Social Sciences on the main campus at New Brunswick, and the Library of Science and Medicine on the Busch campus at Piscataway. Their reference departments combined together are comparable to the central reference departments at either Elmer Holmes Bobst Library at New York University or Frank Melville, Jr. Memorial Library at Stony Brook. Therefore, Alexander Library and the Library of Science and Medicine were treated as one central reference department. All three universities have small satellite departmental libraries that were not included in the study.

Various types of catalogs, whose records were arranged in a number of different ways, were consulted by partici- 
pants in the study. In addition to the more common card catalogs, microform catalogs, book catalogs, and serials lists, the reference departments also had access to bibliographic utilities. The Bobst Library at New York University had a fully operational online catalog. This variety was expected to affect to some extent the study's findings, especially those concerned with use of access points. But the effect on use of most bibliographic elements (and thus on most of the findings) should be negligible because the records in all these catalogs and databases were created using standard codes. The catalogs are, therefore, similar in the kinds of elements contained. Twenty-two catalogs and bibliographic utilities were included in the study.

The study was designed to answer the following research questions:

1. For what purposes do reference staff members use the catalog and/or database of a bibliographic utility?

2. Are the majority of catalog and bibliographic utility database searches by the reference staff members participating in this study for known items?

3. Do the reference staff members use the author's name (whether personal or corporate) as the first access point more often than other access points? ${ }^{4}$

4. What is the incidence of use of each element of the bibliographic record?

Though the findings apply only to the four libraries studied and, thus, define only a small part of the overall picture, they are suggestive for the field as a whole. The findings may also suggest strengths and/or shortcomings in reference service at the four libraries.

The study also raises the question of whether there should be a relationship between the findings obtained from catalog use studies and the arrangement and composition of catalogs, catalog codes, and bibliographic records. Perhaps extent of use of a given bibliographic element is not a sufficient reason for its inclusion or exclusion from the code and the records created using that code. The idea that there should be such a relationship, however, is not new.

\section{METHODOLOGY}

Scripted interviews were selected as the means of collecting the data. The intention was to conduct an equal, or nearly equal, number of interviews at each of the libraries over a relatively long period of time. Six specific hours of each day were set aside for interviewing at each library (two in the morning, two in the afternoon, and two in the evening). A goal was to conduct four interviews each hour, roughly one every fifteen minutes. The interviewer attempted to be as unobtrusive as possible and strove for accuracy when recording the data. The entire study population of seventyfour staff members participated in the interviewing. A period including a major portion of the Fall and Spring terms of the 1984/85 academic year yielded data on all normal catalog activities, providing an accurate description of the departments' searching practices. That the search activities recorded would prevail during any period of time is a reasonable assumption. ${ }^{6}$

\section{Evaluation of the Study}

The interview schedule developed and employed for the study was a successful instrument for gathering the data. The procedure followed during interviewing-including use of a script, striving for accuracy, aiming for a specific number of interviews during each hour, attempting unobtrusiveness, and spending an equal amount of time at each library-facilitated the accumulation of an unbiased sample of interviews.

Achieving an even distribution of the interviews among all the participating reference staff members was difficult because some members spent much more time at the reference desk and did more searches than others. In addition, some reference staff members were much more eager to do searches while others avoided searching, doing so only when necessary. More searching was done at one or two of the libraries than at the 
rest. Although these factors have a direct affect on the findings, they do not invalidate the study. The study's data clearly represent the searching done in the catalogs and bibliographic utility databases of the libraries during the period of the study.

\section{FINDINGS}

For the purposes of this study, the investigator analyzed the data gathered from 1,721 separate searches. Of the total, 515 occurred at Frank Melville, Jr. Library, 622 at Elmer Holmes Bobst Library, 354 at Archibald Stevens Alexander Library, and 230 at Rutgers' Library of Science and Medicine. The total number of searches for the two Rutgers libraries, 584, is roughly comparable to those of the two other libraries in the study: $29.9 \%$ of the total came from Melville Library, $36.1 \%$ from Bobst Library, and $34 \%$ from the two Rutgers libraries.

The sums of searches attributable to individual staff persons ranged from one to 139 per staff member. This disparity in numbers affected the study's findings. Some staff members influenced the findings significantly, others very little.

\section{Research Question: For What Purposes} Do Reference Staff Members Use the Catalog and/or Database of a Bibliographic Utility?

Analysis disclosed that the reference staff members used catalogs and bibliographic utility databases for many purposes (see table 1). Those most often cited were to assist patrons working on course papers, to assist patrons interested in finding something to read for enjoyment or edification, to locate information needed for interlibrary loan transactions, to locate information used in the collection development process, to assist patrons with classroom reading assignments, and to assist patrons working on theses. All were predictable reasons for searching catalogs and databases in academic research libraries.

Research Question: Are the Majority of Catalog and Bibliographic Utility Data-
TABLE 1

INCIDENCE OF USE OF EACH PURPOSE IN RANKED ORDER OF FREQUENCY

\begin{tabular}{|c|c|c|}
\hline $\begin{array}{l}\text { Purpose of } \\
\text { the Search }\end{array}$ & $\begin{array}{l}\text { No. } \\
\text { of Uses }\end{array}$ & $\begin{array}{c}\% \\
\text { of Total } \\
\text { Number } \\
\text { of Uses }\end{array}$ \\
\hline $\begin{array}{l}\text { 1. Patron working on } \\
\text { course paper }\end{array}$ & 446 & 25.9 \\
\hline 2. Patron interested in & & \\
\hline $\begin{array}{l}\text { finding something to } \\
\text { read for enjoyment or } \\
\text { edification }\end{array}$ & 431 & 25.0 \\
\hline 3. Interlibrary loan & & \\
\hline transaction & 227 & 13.2 \\
\hline by staff member & 146 & 8.5 \\
\hline $\begin{array}{l}\text { 5. Patron with classroom } \\
\text { reading assignment }\end{array}$ & 124 & 7.2 \\
\hline 6. Information needed by & & \\
\hline $\begin{array}{l}\text { patron for thesis } \\
\text { 7. Catalog maintenance by }\end{array}$ & 89 & 5.2 \\
\hline staff member & 52 & 3.0 \\
\hline $\begin{array}{l}\text { 8. Patron needing } \\
\text { information for work to } \\
\text { be published }\end{array}$ & 44 & 2.6 \\
\hline $\begin{array}{l}\text { 9. Professional curiosity on } \\
\text { the part of staff member }\end{array}$ & & \\
\hline 10. Patron seeking & 33 & 1.9 \\
\hline job-related information & 33 & 1.9 \\
\hline $\begin{array}{l}\text { 11. Professor preparing for } \\
\text { teaching }\end{array}$ & 31 & 1.8 \\
\hline $\begin{array}{l}\text { 12. Staff member compiling } \\
\text { bibliography }\end{array}$ & 21 & 1.2 \\
\hline 13. Teaching done by staff & & \\
\hline $\begin{array}{l}\text { member } \\
\text { 14. Preparation for oral }\end{array}$ & 10 & 0.6 \\
\hline $\begin{array}{l}\text { presentation } \\
\text { 15. Collection maintenance }\end{array}$ & 8 & 0.5 \\
\hline by staff member & 8 & 0.5 \\
\hline $\begin{array}{l}\text { 16. Staff member seeking } \\
\text { information for work to } \\
\text { be published }\end{array}$ & & 0.0 \\
\hline 17. Patron with class film & & 0.3 \\
\hline 18. Compiling bibliography & 5 & 0.3 \\
\hline $\begin{array}{l}\text { 18. Compiling bibliography } \\
\text { for patron }\end{array}$ & 4 & 0.2 \\
\hline $\begin{array}{l}\text { 19. Information needed by } \\
\text { patron to fill out form }\end{array}$ & & \\
\hline $\begin{array}{l}\text { (not job-related) } \\
\text { Le. }\end{array}$ & 2 & 0.1 \\
\hline $\begin{array}{l}\text { 20. Legal research provided } \\
\text { to patron }\end{array}$ & & 0 \\
\hline 22. Preparation for sermon & & 0.1 \\
\hline Totals & 1,721 & 100.0 \\
\hline
\end{tabular}

base Searches by the Reference Staff Members Participating in this Study for Known Items?

In this study a "known item" search is defined as a search whose first access point includes either a name (whether personal or corporate) or title (including a title keyword). Any search whose first 
access point does not include a name or title is treated as an "unknown item" search. Names which were searched in the catalog as subject headings are treated as unknown item searches. Of the 1,721 searches undertaken in this study, $1,518(88 \%)$ were known item searches, and 203 (12\%) were not known item searches.

\section{However, in recent years some catalog} use studies have shown that in an online environment more subject searching seems to be done.

In previous catalog use studies, the evidence had strongly indicated that patrons do more known item searches than unknown item searches. However, in recent years some catalog use studies have shown that in an online environment more subject searching seems to be done. ${ }^{7}$ In this study, reference staff members conformed to the general finding of most past studies by doing more known item searches than unknown item searches. Further, the percentage $(88.2 \%)$ of known item searches was also much greater than in most of the previous studies. Two possible explanations are that the reference staff members were often doing "'problem" searches for patrons who frequently had a name and/or title in mind. Reference staff were also frequently doing bibliographic work such as interlibrary loan searching in which the author and/or title were usually available.

Research Question: Do the Reference Staff Members Use the Author's Name (Whether Personal or Corporate) as First Access Point More Often than Other Access Points?

Reference staff consulted a wide range of heading types as the first access point of searches. On the one hand, the title by itself was used 914 times (53.1\%). Of these titles, $621(36.1 \%)$ were main en- tries, and $293(17 \%)$ were added entries. On the other hand, the author's name by itself was resorted to 395 times $(22.9 \%)$. Boolean author/title combinations used on database terminals were employed as the first access point 115 times $(6.6 \%)$, while a subject heading or term was used 158 times $(9.2 \%)$.

A number of earlier studies had disclosed that the author was used most often as the first access point. Recent studies such as the one sponsored by the Council on Library Resources in 1982, however, did not. That study found that subject headings were used more often than author. ${ }^{8}$

Research Question: What is the Incidence of Use of Each Element of the Bibliographic Record?

A total of sixty-three separate bibliographic elements were identified primarily in Anglo-American Cataloguing Rules, second edition, with a handful of elements taken from other sources. Incidences of use of added entry access points were not included in this tabulation. Though in a single bibliographic record the elements: "Author" and "Statement of responsibility" may include the same information, they were treated as distinct bibliographic elements. All elements of the bibliographic record may not have equal value, though for many elements there are differing opinions regarding which have more value. Groups of elements serve different functions-one group for reference and retrieval, another for identification and description, and a third for facilitating storage. Some librarians would argue that function affects the value of the elements. Surely, access points used in retrieval are more valuable than many of the descriptive elements. But others would argue that some descriptive elements-the title proper, place, name, and date of publication, and the contents note, to name a few-are also valuable elements, perhaps more so than some access points. In establishing rules, the authors of catalog codes place values on the elements by implication. Code makers may imply further value 
when the rule designates the element required, required if available, or optional information in the record. And cataloging practice at the Library of Congress and at libraries participating in the shared cataloging programs of OCLC and RLIN is based to some extent on the principle that some bibliographic elements have more value than others. This descriptive study does not determine which elements have more value than others, except in so far as reference staff use determines value. This study about reference users and past studies on use identify elements that have "use" value to catalog and database patrons. Determining value through use studies can enhance more traditional ways such as by definition or inference in catalog codes or by statement of principles based on theory or professional opinion.

Only a handful of the elements were consulted twenty-one times or more. Most of the rest were not consulted at all or were consulted only a few times. The elements examined more than twentyone times are listed in table 2.

Thirteen elements, representing $20.6 \%$ of all sixty-three elements and accounting for $96.6 \%$ of the total number of 4,503 uses of all elements, were used more than twenty-one times; only seven elements, representing $11.1 \%$ of all the elements and accounting for $90.7 \%$ of the total number of uses of all elements, were used more than 100 times. These figures lead to the conclusion that most bibliographic elements were not used very often. This finding conforms to data produced in all previous studies.

The picture changes somewhat, however, if librarians take into consideration the likelihood of the various elements appearing in the bibliographic record in the first place because the elements must be there to be used. In this study it would have been difficult for the investigator to have noted and recorded the existence or nonexistence of each bibliographic element in the record. And given the variety of rules and cataloging practices reflected in the catalog of a large university library, it would be difficult to reach any quantitative estimate of
TABLE 2

INCIDENCES OF USE OF

BIBLIOGRAPHIC ELEMENTS

USED MORE THAN

TWENTY-ONE TIMES

(IN RANKED ORDER OF FREQUENCY)

\begin{tabular}{|c|c|c|c|}
\hline $\begin{array}{l}\text { Bibliographic } \\
\text { Element }\end{array}$ & $\begin{array}{c}\text { No. } \\
\text { of Uses }\end{array}$ & $\begin{array}{l}\% \text { of } \\
\text { all } \\
\text { Uses }\end{array}$ & $\begin{array}{l}\% \text { of } \\
\text { all } 1,721 \\
\text { Searches }\end{array}$ \\
\hline 1. Title proper & 1,487 & 33.0 & 86.4 \\
\hline 2. Author & 871 & & \\
\hline $\begin{array}{l}\text { 3. Library or branch } \\
\text { library location }\end{array}$ & & & \\
\hline information & 615 & 13.7 & 35.7 \\
\hline 4. Call number & 594 & 13.2 & 34.5 \\
\hline 5. Chronological & & & \\
\hline serials) & 259 & 5.8 & 15.0 \\
\hline $\begin{array}{l}\text { 6. Date of } \\
\text { publication }\end{array}$ & & & \\
\hline distribution, etc. & 129 & 2.9 & 7.5 \\
\hline $\begin{array}{l}\text { 7. Numeric and/or } \\
\text { alphabetic } \\
\text { designation (for }\end{array}$ & & & \\
\hline serials) & 129 & 2.9 & 7.5 \\
\hline $\begin{array}{l}\text { 8. Place of } \\
\text { publication }\end{array}$ & & & \\
\hline $\begin{array}{l}\text { distribution, etc. } \\
\text { 9. Name of }\end{array}$ & 72 & 1.6 & 4.2 \\
\hline $\begin{array}{l}\text { publisher, } \\
\text { distributor, etc. } \\
\text { 10. Tracing }\end{array}$ & $\begin{array}{l}71 \\
48\end{array}$ & $\begin{array}{l}1.6 \\
1.1\end{array}$ & $\begin{array}{l}4.1 \\
2.8\end{array}$ \\
\hline 11. Other title & & & \\
\hline information & 27 & 0.6 & 1.6 \\
\hline responsibility & 26 & 0.6 & 1.5 \\
\hline $\begin{array}{l}\text { 13. Acquisitions } \\
\text { information }\end{array}$ & 22 & 0.5 & 1.3 \\
\hline 14. Other & 153 & 3.2 & 8.9 \\
\hline Totals & 4,503 & 100.0 & \\
\hline
\end{tabular}

the probability of each element appearing on the records. Still, the various codes and cataloging practices require certain elements. These elements are "Title proper," "Numeric and/or alphabetic designation (for serials)," "Chronological designation (for serials)," "Place of publication, distribution, etc.," "Date of publication, distribution, etc.," "Extent of item," "Dimensions," "Call number," "Tracing," and "Library or branch library location information."

American Library Association standards require other bibliographic elements if the information is available to the individual cataloging the work, that is, if the work is available for examination by the cataloger. These elements in- 
clude "Author," "'General material designation," "Parallel titles," "'Other title information," "Statement of responsibility," "Edition statement," "Statements of responsibility relating to the edition," "Subsequent edition statement," "Statements of responsibility relating to a subsequent edition statement," "Statement of scale," "Statement of projection," "Name of publisher, distributor, etc.," "Other physical details," "Accompanying material," "Title proper of series," "ISSN of series," "Numbering within series," "Subseries," "Language of the item and/or translation or adaptation (Note)," "Edition and history (Note)," "Dissertation (Note)," "Contents (Note)," "Standard number," "Keytitle," "L.C. Card number," "Circulation information," and "Acquisitions information." Inclusion of the remaining elements in bibliographic records is discretionary, depending on the work, the judgment of the cataloger, or the practice of a particular library. ${ }^{10}$

Therefore, in general, this study's findings on frequency of bibliographic element use correspond to those in past studies.

An examination of the frequencies of use of the bibliographic elements in this context reveals that the elements used most frequently in this study correspond to those that would normally be expected to appear on each record, with the exception of "Extent of item" and "Dimensions." Yet, except for "Title proper," each of the required elements discussed above was consulted in less than $51 \%$ of all 1,721 searches observed in the study and accounted for less than $20 \%$ of the total of all 4,503 uses of bibliographic elements. The elements "Extent of item" and "Dimensions," which should appear on most, if not all, records, have very low frequencies of use.
Except for "Author" and "Name of publisher, distributor, etc.," the elements that would appear in records if the information were available to the cataloger at the time of cataloging were also used infrequently. And, as would be expected, discretionary elements have the lowest frequency of use. Most elements, including those in the discretionary category, probably appear on the bibliographic record more frequently than they were used in the searches observed during this study.

Previous catalog use studies disclosed that the elements "Author," "Title proper," "Call number," and "Date of publication, distribution, etc." were often consulted. ${ }^{11}$ All of these elements have been required in bibliographic records for many years. The same elements were also frequently used in this study. Previous studies found that the elements "Place of publication, distribution, etc.," "Name of publisher, distributor, etc.," "Edition statement," and "Contents (Note)" were used less frequently, though more so than many other elements. This particular group of elements comprises information required on bibliographic records if available. Except for "Edition statement" and "Contents (Note)," these elements were consulted moderately often in this study. Other types of data elements such as "Dimensions" and "Illustration statement" were rarely used in previous studies and in the present study. Therefore, in general, this study's findings on frequency of bibliographic element use correspond to those in previous studies. Unlike previous findings, this study showed that the elements "Library or branch library location information," "Chronological designation (for serials)," "Numeric and/or alphabetic designation (for serials)," and "Tracing" were also used frequently.

\section{CONCLUSIONS}

This study's main finding was that the reference staff members generally consulted only a limited number of the elements in the bibliographic records examined. A handful of specific kinds of 
elements was consulted in a large number of searches. Librarians would perhaps expect most of these elements to be used frequently because their presence is required in records, but other required elements such as "Extent of item" and "Dimensions" were hardly used at all. For reference purposes, this is the expected result. The data implied that the reference staff members more often than not employed their catalogs only as aids for finding items in the collection. Apart from such bibliographic elements as "Author," "Title proper," "Call number," "'Library or branch library location information," "Numeric and/or alphabetic designation (for serials)," and "Chronological designation (for serials), " most of the information in the bibliographic record was usually ignored. Reference staff members often did not need to differentiate among editions of the same title, consult notes for a more precise understanding of coverage, determine whether the item was illustrated, or check the title of the series. In general, these findings concur with those of all previous catalog use studies that monitored use of bibliographic elements. The same elements (in particular many of those listed above) tended to be heavily used in all of these studies. In this respect the findings of all the studies were similar.

However, some exceptions to this similarity exist. For example, searches whose purpose was "Collection development by staff member" were frequently associated with a few additional bibliographic elements besides those normally used to identify and find items. These elements were "Place of publication, distribution, etc.," "Name of publisher, distributor, etc.," and "Date of publication, distribution, etc." Though reference staff members doing the searches in this particular category tended to consult a few more elements, the total number of elements consulted was nevertheless restricted to just a few.

Heavy use of bibliographic elements other than those normally consulted to help locate an item was not so apparent in any of the catalog use studies done previously because most of those studies excluded staff members from the population surveyed. While a few did include staff in their study populations, they were a small proportion of the overall study population. For this reason, no separate findings unique to this particular user group were revealed in any of the previous studies.

\section{This study's main finding was that the reference staff members generally consulted only a limited number of the elements in the bibliographic records examined.}

This study's finding that reference staff members used only part of the bibliographic record suggests a possibility that these staff members may be neglecting their catalogs' potential for enhancing the quality of service to patrons. Though this study is descriptive and does not measure the quality of reference service, the finding raises the questions as to whether more skilled reference staff members might have made more and better use of all the bibliographic elements. In a recent article published in the Journal of Academic Librarianship, Peter Hernon and Charles McClure maintained that "unobtrusive testing conducted over the past two decades" has revealed that "serious problems exist in the quality of reference desk service provided in many academic and public libraries throughout the United States. "12 One general finding derived from all these unobtrusive studies indicated that many reference staff members provide only "half-right" answers to questions. Specifically, Hernon and McClure's analysis of the data related to this general finding revealed that reference staff members in the libraries studied, regardless of level of experience, correctly answered about $55 \%$ of the factual and bibliographic questions they received. Perhaps one reason for this was 
that they were not providing information that could have been found in bibliographic records. Perhaps the "behavioral" data on catalog consultation that shows low frequency of use of elements reflects insufficient skill, ignorance of the potential of the bibliographic elements in answering questions, lack of time to do thorough bibliographic investigation, or a combination of all three. But, unless and until more specific studies are done on this possible link between catalog use and bibliographic competence, the relationship is suggestive at best. Still, the available data do suggest the need for library administrators and library educators to consider giving more attention to increasing librarians' bibliographic skills as well as their commitment to professional effectiveness.

\section{This study's finding that reference staff} members used only part of the bibliographic record suggests a possibility that these staff members may be neglecting their catalogs' potential for enhancing the quality of service to patrons.

Another implication relates to the nature of the online catalog systems being used or developed at the four libraries studied and, by extension, to other university libraries. The information provided by this study and other catalog use studies may be helpful in planning and developing these online catalog systems. The libraries undoubtedly recognize the need for full bibliographic records. Library staff such as acquisitions, collection development, and catalog librarians should consult these complete records in the course of their work. The developers of the public user interface portion of the libraries' online catalogs may, however, want to include only a brief display, with a limited number of specified bibliographic elements derived from the full record. The findings of this present study and those of other catalog use studies can help these individuals determine which elements to include in this brief display. The entries could include minimal cataloging information whose main purpose would be to help patrons and reference staff members locate items in the collection. Some libraries have done this already.

Although in a scientific sense it cannot be argued that the findings of this study represent what is happening at other academic research libraries across the country, the findings do indicate what may be happening in some of them. If that is the case, then the option of referring to the findings of this and other catalog use studies when planning and developing the finding list displays of online catalog systems may be applicable in other libraries.

\section{Further Research Needed}

This study provided information from four libraries about the catalog and bibliographic utility database use practices of reference staff members, a catalog user group which had not previously been studied. However, the profession needs catalog use studies which concentrate on gathering data about the searching practices of library staff members from all departments in many libraries. And studies with the combined goals and methodologies for determining catalog use and measuring the quality and effectiveness of bibliographic searching in the course of providing reference service to patrons may yield a still more sophisticated understanding of use and potential use of bibliographic information. These particular studies should explore such issues as whether better use of bibliographic elements improves reference service. The data should be collected in such a way that comparison of use practices among the various departments of a library and among libraries is possible. Comprehensive, empirical survey studies which investigate catalog use by staff in many libraries would be particularly desirable, though such studies are difficult to accomplish.

The reason for conducting these stud- 
ies is to learn more about how library personnel consult catalogs and bibliographic utility databases. Once this knowledge becomes available, it should be compared with what is already known about patron use. In the future, all of this information could then be consulted whenever professional librarians consider revising cataloging codes, public catalog arrangements, and/or the content of bibliographic records. The main purpose of catalogs and bibliographic utility databases is to serve as indexes to the holdings of libraries. As such, they exist for consultation by vari-

\section{The reason for conducting these studies is to learn more about how library personnel consult catalogs and bibliographic utility databases.}

ous user groups. Thus, catalog and database use ought to play a part in the development of cataloging theory and practice. Knowledge of use can contribute an important empirical base for cataloging.

\section{REFERENCES AND NOTES}

1. Elaine Svenonius, "Directions for Research in Indexing, Classification, and Cataloging," Library Resources and Technical Services 25:99 (Jan./Mar. 1981); Alan Seal, "Experiments With Full and Short Entry Catalogues; A Study of Library Needs," Library Resources and Technical Services 27:144-47 (Apr./June 1983).

2. Richard Palmer, Computerizing the Card Catalog in the University Library: A Study of User Requirements, Research Studies in Library Science, no.6 (Littleton, Colo.: Libraries Unlimited, 1972), p.25, 43-45. Some studies have found that one or two additional elements such as name of publisher and edition statement were also rather heavily used. Hillas MacLean, "Using the Library Catalogue," New Zealand Libraries 36:167 (June 1972); Arthur Maltby and Russell Sweeney, "The UK Catalogue Use Survey," Journal of Librarianship 4:194, 195 (July 1972).

3. The term "search" is defined as the employment by one staff member of one catalog or bibliographic utility database, with one purpose provided as the reason for each employment. Any number of access points may be used in one search and additional elements of a record or records may be consulted. A search was concluded when the searcher ceased searching in that catalog or database or changed purpose.

4. The term "use" is defined as the act of examining bibliographic records found in a card catalog, online catalog, book catalog, microtext catalog, or database of a bibliographic utility in order to procure information provided by the different elements of the description.

5. Michael Gorman, A Study of the Rules for Entry and Heading in the Anglo-American Cataloguing Rules, 1967 (London: Library Association, 1968), p.66-67.

6. Following "Guidelines for the Protection of Human Subjects in Research" listed in the Columbia University School of Library Service's "Doctoral Student's Handbook," the researcher kept the participants in the study anonymous. Columbia University, School of Library Service, "Doctoral Student's Handbook," 1st ed. (New York, 1982, Typewritten), p.29-30.

7. Karen Markey, Subject Searching in Library Catalogs: Before and After the Introduction of Online Catalogs (Dublin, Ohio: OCLC, 1984), p.76-78.

8. Gary S. Lawrence, Users Look at Online Catalogs: Results of a National Survey of Users and Nonusers of Online Public Access Catalogs, final report. (Berkeley, Calif.: University of California, Library Studies and Research Division, 1982), p.41-44.

9. James Krikelas, "Catalog Use Studies and Their Implications," in Advances in Librarianship, v.3, ed. Melvin J. Voigt (New York: Seminar Press, 1972), p.201.

10. Anglo-American Cataloguing Rules, 2d ed. (Chicago: American Library Assn., 1978), p.11-82, 247-69; Anglo-American Cataloging Rules: North American Text (Chicago: American Library Assn., 1967), p.11-23, 191-246; A.L.A. Cataloging Rules for Author and Title Entries, 2d ed. (Chicago: American Library Assn., 1949), p.3-16; Library of Congress, Descriptive Cataloging Division, Rules for Descriptive Cataloging in the Library of Congress (Washington, D.C.: Library of Congress, 1949), p.7-99. 
11. Anglo-American Cataloguing Rules, 2d ed. (Chicago: American Library Assn., 1978), p.11-82, 247-69; Anglo-American Cataloging Rules: North American Text (Chicago: American Library Assn., 1967), p.11-23, 191-246; A.L.A. Cataloging Rules for Author and Title Entries, 2d ed. (Chicago: American Library Assn., 1949), p.3-16; Library of Congress, Descriptive Cataloging Division, Rules for Descriptive Cataloging in the Library of Congress (Washington, D.C., Library of Congress, 1949), p.7-99.

12. Peter Hernon and Charles R. McClure, "Library Reference Service: An Unrecognized Crisis," Journal of Academic Librarianship 13:69-71 (May 1987).

13. Seal, "Experiments With Full and Short Entry Catalogues," p.144-49; Stephen R. Salmon, "Characteristics of Online Public Catalogs," Library Resources and Technical Services 27:36-67 (Jan./Mar. 1983). 